HENRY WILLIAM HILLIND

\title{
EXPLOITING THE CROWD: THE NEW ZEALAND RESPONSE TO EQUITY CROWD FUNDING
}

Submitted for the LLB (Honours) Degree

Faculty of Law

Victoria University of Wellington

2014 


\section{Table of Contents}

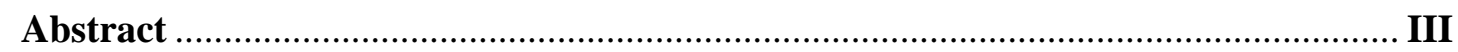

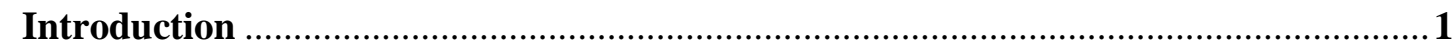

Defining Equity Crowd Funding ...............................................................................

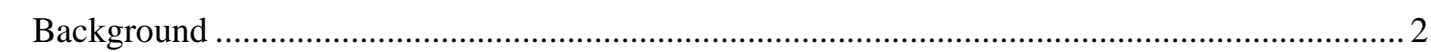

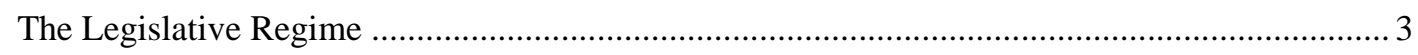

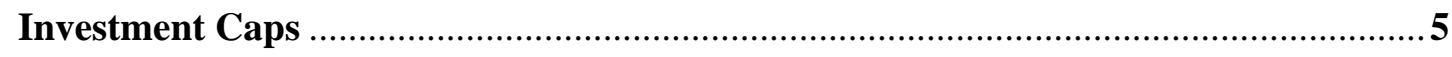

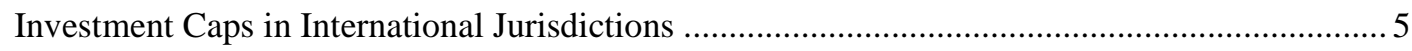

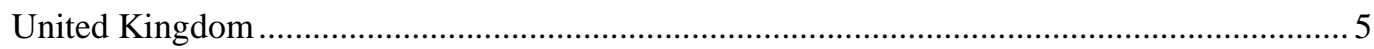

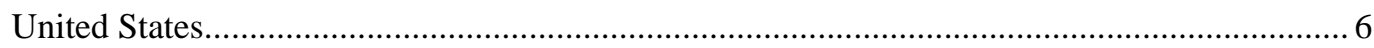

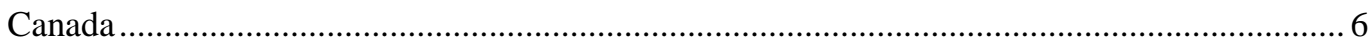

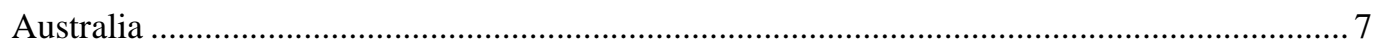

Italy

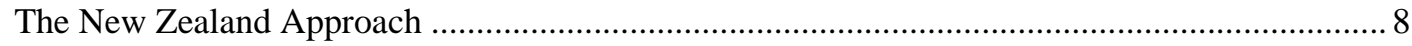

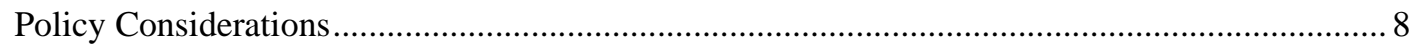

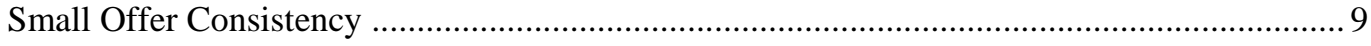

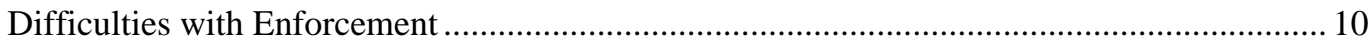

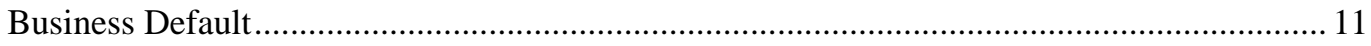

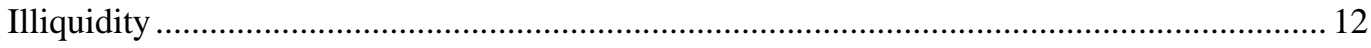

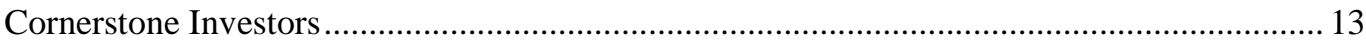

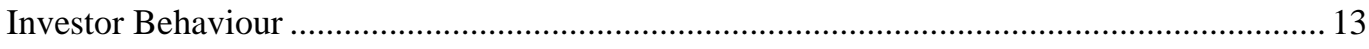

Other Investor Protection Obligations ................................................................. 14

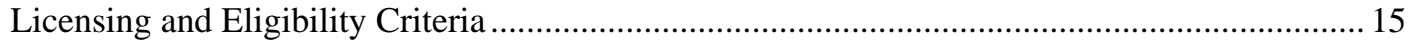

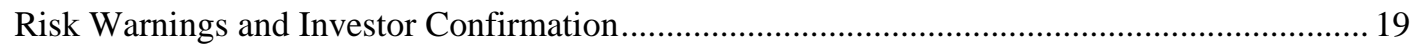

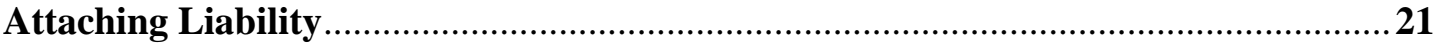

Liability for Breach of Licence Obligations under Part 6 .............................................................. 21

Liability for Breach of Fair Dealing Obligations under Part 2 …................................................. 23

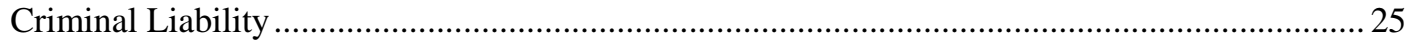

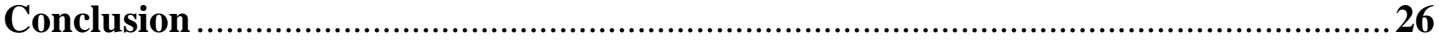

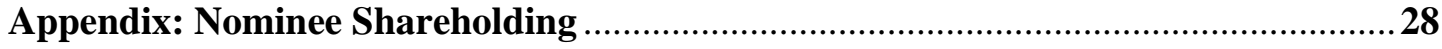

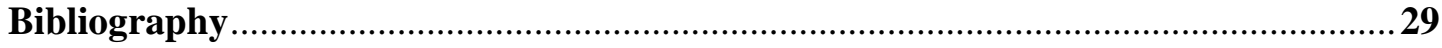




\begin{abstract}
The crowd funding exclusion in the Financial Markets Conduct Act 2013 allows issuers, often innovative start-up businesses, to raise up to $\$ 2,000,000$ in a 12 month period from retail investors through an internet platform provided by a licensed intermediary service, without the need for the product disclosure statement and on-line disclosures usually required under Part 3 of the Act. In order to protect the interests of investors in a market with a high risk of negligible return, other protections need to be provided. International jurisdictions have imposed investor caps, but New Zealand has failed to do so. This essay argues that, particularly in light of shortcomings with other aspects of crowd funding investor protections, a mandatory investor cap of five per cent of the amount being raised should be imposed, to protect investors both from the high risks of venture capital investing and from their own inexperience in this new and rapidly developing market.
\end{abstract}

Key words: "securities", "equity", "investment", "crowd funding" 


\section{Introduction}

The Financial Markets Conduct Act 2013 (FMC Act) comes at an opportune time to reform securities law as New Zealand's financial markets continue to develop in new directions to embrace the internet era. Internationally, start-up businesses are increasingly turning to the realms of cyberspace to gain support for their products and ideas, particularly through crowd funding platforms, due to the reduction in marketing, distribution and transactional costs. ${ }^{1}$

The newest form of crowd funding raises capital by offering unlisted equity shares for issue to the public through internet platforms. This is commonly used to encourage the development and growth of early-stage entrepreneurial businesses. Due to the nature of such businesses, compliance costs associated with full disclosure requirements are usually unviable. Increasingly, governments see it as desirable to promote this type of market with flexible regulatory regimes that loosen disclosure requirements without limiting who can invest. The FMC Act allows for the creation of a crowd funding exclusion, which is now in force. ${ }^{2}$

Crowd funding is a high risk investment. Venture businesses have high failure rates internationally of around 75 per cent. ${ }^{3}$ Other risks include higher vulnerability to fraud and lack of liquidity. ${ }^{4}$ It is important these risks are balanced by investor protection mechanisms, allowing flexibility for the market to develop without exposing investors to significant risks.

This essay argues that the regulations should impose a mandatory investor cap that is proportional to the amount an issuer is raising. A cap of five per cent of the amount being raised is appropriate, with the option of stricter caps imposed by the platform provider. In

\footnotetext{
${ }^{1}$ Financial Conduct Authority The FCA's regulatory approach to crowd funding over the internet (policy statement 14/4, United Kingdom, 6 March 2014) at 40.

2 Minister of Commerce "Crowd funding gets green light" (press release, 27 February 2014). See "Financial Markets Legislation (Phase 1) Commencement Order 2014, cls 2(1)(g)(iii) and 2(1)(h)(vii), which bring into force FMC Act sch 1, cl 6 (the crowd funding exclusion) and sch 4, cl 59 (which treats the Securities Act 1978, s 5(1) as including an exemption from Part 2 of that Act for FMC Act, sch 1 exclusions) from 1 April 2014."

${ }^{3}$ Deborah Gage "The Venture Capital Secret: 3 Out of 4 Start-Ups Fail" The Wall Street Journal (online ed, New York, 19 September 2012).

${ }^{4}$ Eleanor Kirby and Shane Worner "Crowd-funding: An Infant Industry Growing Fast" (February 2014) International Organization of Securities Commissions <www.iosco.org $>$ at 36.
} 
addition, more prescription of warning statements is needed, consistent with the approach internationally. The need for protective measures is exacerbated by the difficulties in attaching liability to platform providers and issuers under the exclusion.

\section{Defining Equity Crowd Funding}

\section{A Background}

Crowd funding is "a way in which people, organisations and businesses can raise money through online portals ... to finance or re-finance their activities and enterprises". ${ }^{5}$ Typically such a process involves "pooling a large number of small contributions ... generally over the internet". ${ }^{6}$ Internationally it is a growth industry, raising USD 2,700,000,000 and successfully funding over 1,000,000 campaigns in $2012 .^{7}$ This figure accounts for all four types of crowd funding: donation, reward, equity and debt.

Donation and reward crowd funding are the largest contributors to the crowd funding economy. They are not regulated by financial market laws as they are not classed as investments. Typically they support creative projects and can involve any sort of reward, from a simple thank you to a physical product.

Equity and debt crowd funding are types of "financial return" crowd funding, ${ }^{8}$ which has typically been heavily regulated in most jurisdictions until recently as it falls within the ambit of securities law. This is understandable as investments in start-up businesses carry high risks alongside the potential for big returns. Access to equity crowd funding has the benefit of giving initial supporters of a business a vested interest in its continued success. Oculus VR raised USD 2,400,000 from 9,522 crowd backers through reward crowd funding in 2012 for the development of its virtual-reality gaming goggles. The founders and venture investors received substantial returns when the company sold to Facebook in

\footnotetext{
${ }^{5}$ Financial Conduct Authority The FCA's regulatory approach to crowdfunding (and similar activities) (Consultation Paper 13/13, United Kingdom, 24 October 2013) at 4.

${ }^{6}$ Ministry of Business, Innovation and Employment Financial Markets Conduct Bill: Officials' Report to Commerce Committee (24 July 2012) at [116].

7 Massolution "2013CF: The Crowdfunding Industry Report" (11 April 2013) Crowdsourcing $<$ www.crowdsourcing.org $>$ at 9.

${ }^{8}$ Kirby and Worner, above n 4, at 4.
} 
March 2014 for USD 2,300,000,000. ${ }^{9}$ If the company had raised capital through equity crowd funding, the backers would have shared in those profits.

\section{B The Legislative Definition}

Under the FMC Act, an offer of financial products, which includes equity securities, ${ }^{10}$ requires disclosure under Part 3 of the Act unless an exclusion under Part 1 of Schedule 1 applies. ${ }^{11}$ Disclosure involves preparing a Product Disclosure Statement (PDS) and lodging information on the register, ${ }^{12}$ the contents of each prescribed by regulation. ${ }^{13}$ The purpose of the PDS is to provide information that is likely to assist a prudent but nonexpert person to decide whether or not to acquire the financial products. ${ }^{14}$ The register entry must contain all material information relating to the offer that is not contained in the PDS. ${ }^{15}$ This disclosure is costly, time-consuming and has significant liability attached where compliance is not adhered to, making it impractical for entrepreneurial enterprises which historically turn to excluded investors for funding, such as venture capitalists and angel investors.

An offer of financial products has since 1 April 2014 been excluded from the disclosure requirements under Part 3 (and exempt from the Securities Act until it is repealed) ${ }^{16}$ if it is made by or through a licensed intermediary (platform provider) in the course of supplying prescribed intermediary services covered by its market services license. ${ }^{17}$ Prescribed intermediary services are crowd funding services and peer-to-peer lending services. ${ }^{18}$ Crowd funding platforms are services that provide "a facility by means of which offers of shares in a company are made", for the purpose of facilitating "the matching of companies who wish to raise funds with many investors who are seeking to invest relatively small amounts". ${ }^{19}$ This is different to peer-to-peer lending, which involves offers of debt

\footnotetext{
${ }_{9}^{9}$ Ari Levy "Crowdfunding Lures Investors Seeking Stock Over Goggles" Bloomberg News (online ed, New York, 9 April 2014).

${ }^{10}$ Section 7(1).

11 Section 39.

12 Section 48.

13 Section 57(1).

${ }^{14}$ Section 49.

${ }^{15}$ Section 57(1)(b).

${ }^{16}$ Schedule 4, cl 59.

${ }^{17}$ Schedule 1, cl 6.

${ }^{18}$ Financial Markets Conduct (Phase 1) Regulations, reg 15.

${ }^{19}$ Regulation 16(1)(a).
} 
securities to borrowers who are seeking loans for "personal, charitable, or small business purposes". ${ }^{20}$

Exclusions from the disclosure regime are traditionally justified where investors are assumed to either have the expertise to protect themselves, ${ }^{21}$ where the investor is "protected by the inherent restraints on an issuer of a social and business kind"22 or where the investor is assumed to be able to obtain information relevant to the securities offered. ${ }^{23}$ These are policy reasons for exclusions where the "need for protection of the investor is outweighed by the costs associated with giving it". ${ }^{24}$ The crowd funding exclusion reduces compliance costs, but is not supported by any of the traditional investor protection policy considerations as it is an offer to the public. Instead, the crowd funding exclusion reflects the policy of the Business Growth Agenda, which seeks to create opportunities for "new and innovative forms of capital raising" to support high-growth businesses to raise money more efficiently. ${ }^{25}$ This approach is consistent with the purposes of the Act. ${ }^{26}$

Although an issuer through a crowd funding service does not need to prepare a PDS or make register entries, that issuer is still bound by the other provisions of the FMC Act and there are specific provisions in the regulations applicable to both issuers and platform providers. Even with these regulations, the overall effect is to relax the previously strict enforcement of disclosure obligations for this type of service, with commentators indicating the exclusion "recognises ... the fundamental role of the internet in business and communities", providing retail investors and businesses with more flexibility and control in how they respectively invest and raise risk capital. ${ }^{27}$

\footnotetext{
${ }^{20}$ Regulation 16(1)(b).

${ }^{21}$ Lawrence v Registrar of Companies [2004] 3 NZLR 37 (CA) at [32].

${ }^{22}$ At [31].

${ }^{23}$ Securities Commission v Kiwi Cooperative Dairies Ltd [1995] 3 NZLR 26 (CA) at 32.

${ }^{24}$ Lawrence v Registrar of Companies, above $n$ 21, at [27].

${ }^{25}$ Ministry of Business, Innovation and Employment Business Growth Agenda: Future Direction 2014 (June 2014) at 37.

${ }^{26}$ Sections 3(b) and 4(d).

27 Hayley Buckley "Exploding the crowdfunding myths" The National Business Review (online ed, New Zealand, 12 April 2014).
} 


\section{Investment Caps}

An issue at the heart of the crowd funding movement is whether the amount a retail investor can invest through crowd funding platforms should be capped. Imposing such caps reflects a policy of protecting less sophisticated investors from losing their entire investment portfolio due to the high risk nature of most crowd funded business, by effectively mandating diverse investing. These caps would complement other protections such as risk warnings and alternative, limited disclosures. Competing policy considerations include the practicality of caps being complied with and the restrictions they place on growth in the equity crowd funding economy by limiting access to capital, particularly from cornerstone investors. The approach to investor caps has varied significantly across different jurisdictions.

\section{A Investment Caps in International Jurisdictions}

\section{United Kingdom}

The United Kingdom Financial Conduct Authority (FCA) ${ }^{28}$ has recently implemented rules in the Conduct of Business Sourcebook (COBS) which allow retail clients to invest through crowd funding platforms from 1 April 2014. ${ }^{29}$ Alongside high net worth and certified or self-certified sophisticated investors, ${ }^{30}$ "restricted investors" may now receive direct-offer financial promotions relating to non-readily realisable securities. ${ }^{31} \mathrm{~A}$ "restricted investor" is an individual who certifies they will not invest more than 10 per cent of their net assets in a 12-month period into non-readily realisable securities and accepts that such securities hold a significant risk of losing the entire investment. ${ }^{32}$ The cap does not apply to advised retail clients. ${ }^{33}$

\footnotetext{
${ }^{28}$ An independent regulatory body with rule-making powers; see Financial Services and Markets Act 2000 (UK), s 137A.

${ }^{29}$ Crowdfunding and the Promotion of Non-Readily Realisable Securities Instrument 2014 (UK).

${ }^{30}$ See Financial Conduct Authority Conduct of Business Sourcebook at 4.12.6 R, 4.12.7 R and 4.12.8 R.

${ }^{31}$ At 4.7.7 R.

${ }^{32}$ At 4.7.10 R.

${ }^{33}$ At 4.7.8 $\mathrm{R}$ and 9.2.1 $\mathrm{R}$.
} 


\section{United States}

The United States Securities and Exchange Commission (SEC) announced proposed rules on 23 October $2013^{34}$ to regulate crowd funding under Title III of the Jumpstart Our Business Startups Act (JOBS Act), with a focus on investor protection. ${ }^{35}$ The JOBS Act provides an exemption from usual registration requirements ${ }^{36}$ for offers through crowd funding platforms that have in place issuer and investor caps. ${ }^{37}$ The issuer cap imposes an aggregate cap of USD 1,000,000 in any 12-month period on the amount an issuer may raise through crowd funding portals. ${ }^{38}$ The investor cap is scaled, allowing aggregate investments in any 12-month period of up to either 10 per cent of an investor's annual income or net worth if it is equal to or more than USD 100,000 with a maximum cap of USD 100,000, or five per cent of an investor's annual income or net worth if it is less than USD 100,000 with a minimum cap of USD 2,000. ${ }^{39}$

\section{Canada}

The Ontario Securities Commission (OSC) proposed investor caps for equity crowd funding of CAD 2,500 for investments in a particular issuer and CAD 10,000 in total crowd funding investments during a calendar year. ${ }^{40}$ In the proposed exemption, the OSC confirmed these caps ${ }^{41}$ alongside a CAD 1,500,000 cap on the amount an issuer may raise in a 12 -month period. ${ }^{42}$

Regulation authorities in Québec, Saskatchewan, New Brunswick, Manitoba and Nova Scotia have proposed similar crowd funding rules including the same investment caps. ${ }^{43}$

\footnotetext{
34 United States Securities and Exchange Commission "SEC Issues Proposal on Crowdfunding" (press release, 23 October 2013).

35 Jumpstart Our Business Startups Act Pub L No 112-106, § 302(c), 126 Stat 306 at 320 (2012).

${ }^{36}$ See Securities Act 15 USC § 77e.

${ }^{37}$ Jumpstart Our Business Startups Act Pub L No 112-106, § 302(a), 126 Stat 306 at 315 (2012).

${ }^{38}$ Securities Act 15 USC § 77d(a)(5)(A).

${ }^{39}$ Securities Act 15 USC $\S 77 d(a)(5)(B)$.

40 Ontario Securities Commission Considerations for new capital raising prospectus exemptions (Consultation Paper 45-710, December 2012) at 59.

${ }^{41}$ Ontario Securities Commission Introduction of Proposed Prospectus Exemptions and Proposed Reports of Exempt Distribution in Ontario (OSC Bulletin Volume 37, Issue 12 (Supp-3) 20 March 2014) at D-49.

${ }^{42}$ At D-48.

43 Canadian Securities Administrators Multilateral CSA Notice of Publication and Request for Comment: Draft Regulation 45-108 respecting Crowdfunding; Draft Policy Statement to Regulation 45-108 respecting Crowndfunding; Draft Blanket Orders in Manitoba, Québec, New Brunswick and Nova Scotia on the Start-
} 
These territories, excluding Saskatchewan where an exemption already exists, ${ }^{44}$ have also proposed a "start-up" exemption for non-reporting issuers which allows two annual capital raises of up to CAD 150,000 with investors capped at CAD 1,500 per investment. ${ }^{45}$ These tighter caps come with lesser disclosure requirements.

\section{Australia}

At present Australia does not have a crowd funding exemption. Following a discussion paper in late 2013, ${ }^{46}$ the Corporations and Markets Advisory Committee have made recommendations for a separate regulatory regime to allow for crowd funding. This regime would involve creating a new category of public companies which "could be adopted for a limited period by entities wishing to raise equity finance from the crowd". ${ }^{47}$ It is important that New Zealand watches the developments in Australia closely due to obligations to work towards a trans-Tasman Single Economic Market. ${ }^{48}$ Consistency in the approach to crowd funding is therefore desirable.

\section{Italy}

The Italian Parliament, which legislated in late 2012 to permit equity crowd funding, ${ }^{49}$ did not set any investor caps other than a EUR 5,000,000 cap on the amount an issuer may raise per year. ${ }^{50}$ Instead, the regulations limit the exemption to innovative start-ups recognised by the Chamber of Commerce ${ }^{51}$ and implement other restrictions such as requiring at least five per cent of backing to be by "professional investors or by banking foundations or by innovative start-up incubators". 52

Up Crowdfunding Prospectus and Registration Exemption; Draft Ammendments to General Order 45-925 Saskatchewan Equity Crowdfunding Exemption (20 March 2014) at 4.

${ }^{44}$ General Order 45-925 - Saskatchewan Equity Crowdfunding Exemption.

${ }^{45}$ Canadian Securities Administrators, above n 43, at 13.

${ }^{46}$ Australian Government Corporations and Markets Advisory Committee Crowd sourced equity funding: Discussion Paper (September 2013).

47 Australian Government Corporations and Markets Advisory Committee Crowd sourced equity funding: Report (May 2014) at 18.

48 Protocol on Investment to the New Zealand - Australia Closer Economic Relations Trade Agreement [2013] NZTS 1 (signed 16 February 2011, entered into force 1 March 2013), art 2(a).

${ }^{49}$ Decreto Crescita 2.0 (DL 179/2012 conv con L 221/2012), art 30 (translation: Growth Decree).

${ }^{50}$ Commissione Nazionale per le Sociea e la Borsa Regalomenti emittenti (October 2013), art 34-ter(1)(c) (translation: Issuer's Regulations).

${ }^{51}$ Commissione Nazionale per le Sociea e la Borsa Regulation on The collection of risk capital on the part of innovative start-ups via on-line portals (July 2013), art 2(1)(c).

${ }^{52}$ Article 24(2). 


\section{B The New Zealand Approach}

The Financial Markets Conduct (Phase 1) Regulations 2014 do not impose a cap on the amount an investor may invest through intermediary services. A cap has been imposed on the amount an issuer may raise of an aggregate $\$ 2,000,000$, which is breached when an issuer "exceeds $\$ 2$ million in any 12-month period" from "relevant offers". ${ }^{3}$ A "relevant offer" is an offer made in reliance on either the exclusion relating to peer-to-peer lending and crowd funding, or the small offers exclusion. ${ }^{54}$

The decision not to impose investor caps in New Zealand is more liberal compared to international jurisdictions, reflecting policy that favours innovation and growth over strict consumer protection. The United States and United Kingdom have both implemented caps relative to the individual investor's income or assets, while Canadian territories have proposed a set cap. Compared to the other common law jurisdictions, New Zealand has taken a far less restrictive approach which may not adequately protect unsophisticated investors.

\section{Policy Considerations}

In considering investor caps, the Minister analysed whether a cap should apply per investor or per issuer and whether the cap should be a fixed amount or should vary according to investor income or wealth. ${ }^{55}$

The exposure draft regulations presented four options for investor caps, the last being no cap at all. ${ }^{56}$ The other options were: a fixed limit of $\$ 15,000$ in shares from any one issuer, ${ }^{57}$ a fixed limit of $\$ 50,000$ in shares from all issuers ${ }^{58}$ or a scaled limit of 10 per cent of gross income or net assets valued above $\$ 100,000$ with a maximum investment cap of

\footnotetext{
${ }^{53}$ Financial Markets Conduct (Phase 1) Regulations, sch 1, cl 4.

${ }^{54}$ Schedule 1, cl 4(3).

55 Cabinet Business Committee "Financial Markets Conduct Regulations Paper 4: Licensing regimes" (27 June 2013) at [136].

56 Ministry of Business, Innovation and Employment Financial Markets Conduct Regulations: First Exposure Draft Commentary and request for submissions (October 2013) at [55].

${ }^{57}$ Financial Markets Conduct (First Exposure Draft) Regulations 2014, reg 27(1)(f).

${ }^{58}$ Regulation 27(1)(g).
} 
$\$ 100,000$, or five per cent of gross income or net assets valued below $\$ 100,000$ with a minimum cap of $\$ 2,000 .^{59}$

The Minister recognised ${ }^{60}$ there is a strong policy argument for imposing investor caps, as the information that investors receive could be variable and there will be uncertainty around what returns will eventuate from a given investment. Receiving returns will likely take longer and the per-investor cap would "reduce the risk that large scale investor losses damage the credibility of equity-based crowd-funding and the regulatory regime as a whole". 61

Despite these reservations, the Minister's preferred approach was not to impose investor caps. Based on the decisions presented by the Minister to the Cabinet Business Committee, it is likely this was because no similar cap would exist for the small offer exclusion and an investor cap would be difficult to enforce. ${ }^{62}$

The following policy considerations are relevant and suggest on balance that investor caps are desirable to protect investors.

\section{Small Offer Consistency}

The Minister asserted a cap "would create incentives for issuers to make separate offers to investors in reliance on the small offer exclusion". ${ }^{63}$ However, the crowd funding and the small offer exclusions serve different purposes. Crowd funding is aimed at a large number of investors who invest "relatively small amounts", ${ }^{64}$ whereas small offers are for where there is "no expectation of regulatory protections or compliance", such as a small business owner receiving funding from an acquaintance. ${ }^{65}$ While small offers can cover some formal offers to members of the public, an issuer would still need to make "personal offers" to a small number of investors willing to invest substantial amounts in order to

\footnotetext{
${ }^{59}$ Regulations 27(1)(h), 27(3) and 27(4).

${ }^{60}$ Cabinet Business Committee, above n 55, at [138].

61 At [138].

62 At [139]-[140].

${ }^{63}$ At [139].

${ }^{64}$ Regulation 16(1)(a)(ii).

65 Cabinet Business Committee "Financial Markets Conduct Regulations Paper 2: Disclosure and General Matters" (27 June 2013) at [59].
} 
meet the issuer's funding goal. Rather than creating an incentive for issuers to focus on a smaller group of potential investors, imposing an investor cap would encourage the issuer to connect more strongly with the crowd to gather support from as many people as possible, which is more consistent with the principle of a large number of investors contributing small amounts. ${ }^{66}$

\section{Difficulties with Enforcement}

The Minister considered caps would be relatively easy to avoid. ${ }^{67}$ Investors could circumvent caps by creating multiple user accounts, using multiple services or investing off-platform, ${ }^{68}$ rendering investor caps a "meaningless protection in practice" ${ }^{69}$ This is not necessarily the case, as more than likely a majority of retail investors would not circumvent the restriction, particularly if doing so would be in breach of the Act. New Zealand could have taken the self-certification approach of the United Kingdom, where a platform needs to ensure the investor has certified they will not breach the cap with no other on-going enforcement obligations. ${ }^{70}$ Another suggested approach was for investors to make a statutory declaration, breach of which would be subject to criminal liability under s 110 of the Crimes Act $1961 .^{71}$ Such an approach may be unjustly burdensome.

Enforcement issues are not in themselves a justifiable reason for not imposing an investor cap where other strong policy considerations indicate there should be one. Selfcertification is a viable option, or alternatively certain enforcement requirements could be implemented, such as each platform ensuring the investor does not breach the cap on its service, or having simple identification checks for user accounts.

\footnotetext{
${ }^{66}$ Pledgeme and Carter Kirkland Morrison Lawyers Financial Markets Conduct Regulations (First Exposure Draft) Regulations 2014 - Table of submissions (Ministry of Business, Innovation and Employment, February 2014) at 45.

67 Cabinet Business Committee "Financial Markets Conduct Acts and Financial Advisers Act 2008 commencement order and regulations" (24 February 2014) at [16] (Obtained under Official Information Act 1982 Request to the Minister of Commerce).

${ }^{68}$ Cabinet Business Committee, above n 55, at [140].

${ }^{69}$ Buckley, above n 27.

${ }^{70}$ Financial Conduct Authority, above n 1, at 43.

${ }^{71}$ Pledgeme and Carter Kirkland Morrison Lawyers, above n 66, at 45.
} 


\section{Business Default}

The majority of entrepreneurial ventures fail. A recent Harvard Business School study found that of over 2,000 high potential venture-backed businesses generally receiving at least USD 1,000,000 between 2004 and 2010, approximately 75 per cent failed to return investors' capital with 30 to 40 per cent returning nothing at all. ${ }^{72}$ Soap manufacturer Bubble and Balm was the first company to raise money through crowd funding in the United Kingdom in 2011 with the issue of 15 per cent of the company's equity for GBP 75,000 , but failed two years later with complete loss of shareholder equity. ${ }^{73}$ Venture capitalists recognise not all entrepreneurial businesses will be successful and crowd funding platforms recommend practising "portfolio diversification" by investing small amounts across a large number of start-ups to mitigate risk. ${ }^{74}$ Diversification is viewed as "critically important to investors in general" due to the high risk of capital loss. ${ }^{75}$

With a high chance that a business will default, it is important investors either:

- do a lot of background research into the venture they are supporting; or

- are made sufficiently aware of the risks to know that they are more likely to lose than to gain; or

- $\quad$ are protected from losing all of their investments by the restriction of an investment cap.

The social media aspect of crowd funding can offer a false sense of security, where instead of due diligence processes and adviser recommendations, investors rely on the wisdom of the crowd to decide whether an investment opportunity is a good one. ${ }^{76}$ An investor that sees a popular project backed by a lot of people is less likely to do their own due diligence in reliance on the popularity of the project.

\footnotetext{
${ }^{72}$ Gage, above $n 3$.

${ }^{73}$ Lucy Warwick-Ching, Tanya Powley and Elaine Moore " Alarm bells for crowdfunding as bubble pops for soap start-up" Financial Times (online ed, London, 31 July 2013).

${ }^{74}$ Seed Invest "Frequently Asked Questions: What do I need to know about early-stage Investing? Are these Investments risky?" <www.seedinvest.com>.

75 James J Williamson "The JOBS Act and Middle-Income Investors: Why It Doesn't Go Far Enough" (2013) 122 Yale LJ 2069 at 2075.

${ }^{76}$ Ministry of Business, Innovation and Employment Financial Markets Conduct Regulations (Discussion Paper, December 2012) ch 9 at [392]. (or at 239.)
} 


\section{Illiquidity}

The FCA in the United Kingdom indicated an important aim of their rules is to "mitigate the liquidity risk investors face when investing in the equity ... securities of small and medium enterprises". ${ }^{77}$ A liquidity risk is the inability for an investor to liquidate an investment once it has been entered, which is particularly significant in private equity where there is little or no secondary market and the equity itself is difficult to value, effectively locking the investor in until maturity. ${ }^{78}$ The United States severely restricts the liquidity of equity crowd funding by placing a ban on share trading for one year except in specified circumstances. ${ }^{79}$ New Zealand is less restrictive, allowing platforms to operate secondary markets if they are "fair, orderly and transparent". ${ }^{80}$ Even where a secondary market does develop, it is generally thinly traded and investors seeking to liquidate their investment sell at a significant loss to face value. ${ }^{81}$

Investors should only be providing funding they do not need for day to day cash flow. ${ }^{82}$ An investor that invests a significant amount of their capital into crowd funding enterprises not only risks losing that money, which could comprise a large amount of their savings, but also will have no access to the capital for an indefinite period, assuming the business is successful enough to eventually make a return.

Investor caps could undermine liquidity by restricting the size of the market, as well as disadvantaging issuers listing towards the end of the annual period. ${ }^{83}$ Instead of encouraging investments in several issuers, a cap could push investors to select fewer issuers as otherwise their investments would be rendered "(relatively) financially insignificant". ${ }^{84}$ This seems contrary to the concept of investing small amounts as it instead encourages investors to make substantial financial investments in many issuers, resulting

\footnotetext{
${ }^{77}$ Financial Conduct Authority, above n 1, at 37.

${ }^{78}$ Kirby and Worner, above $\mathrm{n} 4$, at 36.

79 Securities Act 15 USC § 77d-1(e).

${ }^{80}$ Financial Markets Authority Crowd Funding Part B1: Your guide to applying for a market service licence (1 April 2014) at 18.

${ }^{81}$ Kirby and Worner, above n 4, at 36.

${ }^{82}$ William Foster Financial Markets Conduct Regulations (First Exposure Draft) Regulations 2014 - Table of submissions (Ministry of Business, Innovation and Employment, February 2014) at 42.

83 Wynn Williams Financial Markets Conduct Regulations Discussion Paper - Table of Submissions (Ministry of Business, Innovation and Employment, March 2013) at 809.

${ }^{84}$ Wynn Williams Financial Markets Conduct Regulations (First Exposure Draft) Regulations 2014 - Table of submissions (Ministry of Business, Innovation and Employment, February 2014) at 41-42.
} 
in over-subscription and an unbalanced investment portfolio weighted towards non-readily realisable investments. An investor cap per issuer would encourage a better practice of diversification while reinforcing the core concept of crowd funding: small amounts invested by many people.

\section{Cornerstone Investors}

Imposing investor caps could limit the ability for cornerstone investors to participate in crowd funding platforms. A cornerstone investor is an individual that takes a significant share in the offer. It is asserted that such an investor helps gain momentum for the offer and ultimately leads to a higher rate of success. ${ }^{85}$ However, cornerstone investors do not necessarily need to come within the crowd funding exclusion to take part in funding through crowd funding platforms. An alternative approach is for cornerstone investors to be excluded under a different provision, such as being wholesale investors, with their contributions to businesses disclosed to potential crowd funding investors. Cornerstone investors on policy grounds should be people that fall within another exclusion, not individuals that are inexperienced in investing. This arrangement benefits issuers too, as having a professional investor as your cornerstone investor adds a level of credibility to an offer. ${ }^{86}$

\section{Investor Behaviour}

Inexperienced investors may need protection from themselves, such as where an investor neglects proper due diligence and makes bad investment choices due to investor overoptimism. ${ }^{87}$ An investor cap would help to limit the harm a reckless investor is subject to, as well as limit harm to the industry caused by investors claiming they were misled. A fixed cap could be overly restrictive on more wealthy investors while failing to offer meaningful protection to less wealthy investors for whom it may appear quite large ${ }^{88}$ and significantly above what many would be able to lose without detriment to their overall

\footnotetext{
${ }^{85}$ Snowball Effect Financial Markets Conduct Regulations (First Exposure Draft) Regulations 2014 - Table of submissions (Ministry of Business, Innovation and Employment, February 2014) at 43.

${ }^{86}$ Chee Keong Low "Cornerstone Investors and Initial Public Offerings on the Stock Exchange of Hong Kong" (2009) 14 FJCFL 639 at 649.

${ }^{87}$ Financial Conduct Authority, above n 1, at 13.

${ }^{88}$ Cabinet Business Committee, above n 55, at [142].
} 
savings. ${ }^{89}$ A proportionate cap such as that imposed in the United States would be more appropriate than a fixed cap in this regard.

Attempting to protect reckless investors may be inconsistent with the lack of restrictions on gambling. ${ }^{90}$ The United Kingdom response to such a proposition was quite clear; the FCA refused to comment on that sector as they do not regulate it. ${ }^{91}$ The comparison is not an overly appropriate one, as gambling is a game of chance where the risk of loss is generally well recognised or at least recklessly ignored, whereas the risks of investing in crowd funding are often downplayed and unknown to potential investors, who may think it is a safer investment than it actually is. ${ }^{92}$ There are also significant differences between gambling and crowd funding. In particular, crowd funding is a way of fostering investment in New Zealand's capital markets and therefore to be encouraged.

On balance it is desirable to protect unsophisticated investors. An appropriate cap that could do this would limit the investor to a maximum investment of five per cent of the amount being raised in a particular offer. This approach reflects the principle that crowd funding is about small contributions from a large number of investors, distinguishing it from the small offers exclusion which adequately regulates larger investments.

\section{Other Investor Protection Obligations}

Where investor caps are not mandatory, it would be reasonable to expect some other form of consumer protection consistent with the purposes of the Act. Otherwise, there is an unfair disparity between smaller regulated offers made under the Act and offers excluded by the crowd funding exclusion. Investor caps are closely linked with other investor protection practices. Issuers under the exclusion want to give minimal disclosure to reduce costs, which reinforces the desirability of imposing a mandatory cap.

The main focus of New Zealand regulation applicable to crowd funding is on the obligations of the platform provider, in particular the requirements for licensing under Part

\footnotetext{
${ }^{89}$ Ministry of Business, Innovation and Employment, above n 56, at [55].

${ }^{90}$ Buckley, above n 27.

${ }^{91}$ Financial Conduct Authority, above n 1, at 16.

92 At 14.
} 
6 of the Act. This shifts the costs of compliance away from the issuer and places it with the provider. The focus of licensing the intermediaries, according to the Financial Markets Authority (FMA), is to ensure investors "gets real clarity over what the risks are, so it's not necessarily that they're reducing the risks, but making sure that there is a transparent disclosure of the risks". ${ }^{93}$ This is achieved by imposing disclosure requirements on the provider.

A provider of a crowd funding service must hold a market services licence, ${ }^{94}$ issued at the discretion of the FMA. ${ }^{95}$ A licence is only issued when the eligibility criteria for the particular market service are met. ${ }^{96}$ The service must also be registered under the Financial Service Providers (Registration and Dispute Resolution) Act 2008, have fit and proper persons holding director and senior management positions and the FMA must be satisfied first that the service is capable of effectively performing the service and secondly must have no reason to believe the service will contravene its licensee obligations. ${ }^{97}$ The FMA is permitted to impose certain conditions on the licence. ${ }^{98}$ The provider has obligations under the licence to make a disclosure statement to investors about aspects of the service ${ }^{99}$ and to give warning statements and receive investor confirmation. ${ }^{100}$

\section{A Licensing Eligibility Criteria}

The eligibility criteria for crowd funding services set a high standard for providers. The provider must have an anti-fraud policy, a fair dealing policy and adequate disclosure arrangements. ${ }^{101}$ "[F]air, orderly and transparent systems and procedures" for providing the service are also required. ${ }^{102}$

The provider must have "adequate disclosure arrangements" sufficient to give investors access to, or to enable them to readily obtain, timely and understandable information to

93 "Equity crowd funding a 'high risk of failure'" The New Zealand Herald (online ed, Auckland, 23 April 2014).

${ }^{94}$ FMC Act, s 390.

95 Section 394.

${ }^{96}$ Section 396(a).

${ }^{97}$ Section 396.

98 Section 403.

99 Section 423.

${ }^{100}$ Regulations 27 and 28.

${ }^{101}$ Regulation 17.

102 Regulation 17(1)(a). 
assist them in deciding whether to acquire shares. ${ }^{103}$ Examples from the regulation include initial disclosure or question and answer forums. In deciding whether the disclosure arrangements are adequate, the FMA must have regard to whether any limits are imposed on the amount a retail investor may invest under the service and to the amount that issuers may raise under the service. ${ }^{104}$ The FMA indicate they may also consider other matters such as any checks the platform provider does on issuers. ${ }^{105}$

This criterion indicates that although a mandatory investor cap was not imposed under the regulations, the FMA will take into account any investor caps imposed by the provider in deciding whether the disclosure arrangements are adequate and can require greater disclosure if they are not. The objective of the crowd funding exclusion to provide low cost funding to start-up businesses will be frustrated if these disclosure requirements are too onerous.

The provider must formulate appropriate disclosure policies to compliment any restrictions the provider decides to place on the amount issuers may raise and the amount investors may invest either in total or in a particular issue. Potentially this allows greater customisation and flexibility. However, this could result in issuers looking to raise more being required to comply with heavier disclosure which goes against the purpose of the exclusion. In the United States it could cost upwards of USD 100,000 to raise through a crowd funding portal due to the heavier disclosure required for offers between USD 500,000 and USD 1,000,000 combined with the percentage cut taken by service providers, making public equity crowd funding "one of the costliest forms of (legal) capital raising". ${ }^{106}$ New Zealand must be careful not to require expensive disclosure that could choke the fledgling market, particularly as the market is likely to be relatively small, with only two licensed service providers approved thus far. ${ }^{107}$ There is a risk of over regulating the market that must be balanced with the need to have adequate investor protection. Imposing sufficient investor caps is an appropriate balance to lower disclosure requirements.

\footnotetext{
${ }^{103}$ Regulation 17(1)(d).

${ }^{104}$ Regulation 17(2).

105 Financial Markets Authority, above n 80, at 15.

${ }^{106}$ Brian Korn "SEC Proposes Crowdfunding Rules" Forbes (online ed, New York, 23 October 2013).

${ }^{107}$ Financial Markets Authority "FMA issues first equity crowd funding licences" (press release, 31 July 2014).
} 
It will be for the FMA to determine whether the proposed disclosure processes are sufficient. If they are not, then assuming the platform provider has enforced the approved disclosure processes, it is the FMA that is ultimately at fault for approving processes that are not adequate for the situation. Such decisions are the exercise of delegated executive power and the courts cannot intervene except to the extent of judicially reviewing the decision. One issue with the approach is that the processes are assessed during the licence application, so flexibility is limited to whatever processes are approved by the FMA prior to issuers making offers through the service.

To encourage innovation and efficiency, a flexible approach is desirable subject to careful supervision by the FMA. ${ }^{108}$ Approval of disclosure mechanisms will take a principlesbased approach. ${ }^{109}$ The FMA has given some guidance regarding its expectations by issuing guidelines with minimum standards which should assist in assessing proposed mechanisms and may mitigate concerns around an overly liberal or restrictive approach to licensing. ${ }^{110}$

Disclosure arrangements can include initial disclosure of information, question and answer forums between the investors and the issuer and links to other information sources, as well as carrying out checks on issuers which are disclosed to investors. ${ }^{111}$ At a minimum, the FMA expects a dedicated webpage for each offer on the platform's website with information provided by the issuer that includes: a description of the business; the purpose of the offer; the terms including price, minimum funding sought, amounts raised so far, whether any investor caps apply and the rights attaching to the shares including details of any other securities of the issuer; information about the liquidity of the shares; the names and positions of the directors and senior managers; and arrangements with the issuer to supply required information. ${ }^{112}$

\footnotetext{
${ }^{108}$ Cabinet Business Committee, above n 55, at [126].

${ }^{109}$ At [129].

${ }^{110}$ Ministry of Business, Innovation and Employment Financial Markets Conduct Regulations (Discussion Paper, December 2012) at 239.

${ }^{111}$ Financial Markets Authority, above n 80, at 15.

112 At 16.
} 
The FMA states: ${ }^{113}$

If you don't impose investor caps (or they are high) or the issuer is trying to raise significant amounts of capital, we'd usually expect your arrangements to include extra disclosure such as providing a business plan, details of how funds will be used, key risks and key financial information, such as financial statements.

The FMA's intention is to insist on stronger disclosure where no investor protection is provided through investment caps imposed by the platform provider, resulting in a disclosure regime which, although still flexible to the needs of the platform with the details to be approved at the FMA's discretion, is closer to the sort of disclosure required under a PDS. The provision of key financial information could be less arduous than disclosure for regulated offers, which requires audited financial statements by a qualified auditor. ${ }^{114}$ However, the costs will still be greater than for raises of smaller amounts, which may frustrate the attraction of crowd funding for start-up businesses as being a cost effective method of funding.

The implication of the FMA's guidance is that without investment caps, greater disclosure is expected causing greater expense. The Minister indicated that disclosure should be proportionate to the amount being raised. ${ }^{115}$ This does not support the philosophy behind crowd funding, that it is low cost funding from a large crowd of investors each contributing small amounts. Greater disclosure increases costs significantly which deters issuers while providing little protection to investors to mitigate the identified risks of this type of investing. An approach that would put less pressure on platform providers and the FMA to develop complex disclosure arrangements would be to impose a mandatory cap of five per cent per issue, thereby limiting the risks to investors while keeping the disclosure compliance costs to a minimum. For raises of greater amounts, the expectation could be for greater disclosure unless the provider imposes a stricter cap. This would encourage providers to tailor their policies to the needs of the issuer, by providing the option of either reducing the maximum amount an investor can contribute while keeping disclosure to a minimum, or requiring higher disclosure where the issuer wishes for investors to be able to contribute up to the five per cent.

${ }^{113}$ At 16.

${ }^{114}$ Section 457.

${ }^{115}$ Cabinet Business Committee, above n 55, at [130]. 


\section{B Risk Warnings and Investor Confirmation}

Educating investors about the risks of crowd funding is an important part of protecting them. Investor caps offer some protection from the risks, but proper understanding allows an investor to make their own informed decisions about whether the risks are right for them, promoting confident and informed participation. ${ }^{116}$ As it is a new market it is important that investors recognise and agree to the risks from the outset, otherwise overoptimism may lead to bad investments and accusations by investors that they were misled. ${ }^{117}$

A platform provider is required to display a warning statement on its home page and to an investor before they apply for or otherwise acquire financial products. ${ }^{118}$ The warning tells the investor: that equity crowd funding is risky, involving businesses which are speculative and carry high risks; that the investor could lose their entire investment and must be in a position to bear that risk without undue hardship; that the usual rules for public offers do not apply and the investor has fewer legal protections; and that the investor should "ask questions, read all information given carefully, and seek independent financial advice before committing" to the offer. ${ }^{119}$

Confirmation from the investor must also be obtained which states that the investor understands the risk of losing their entire investment, confirms they can bear the loss without undue hardship, understands that the usual legal protections do not apply to this investment and recognises they may not receive the same information usually required for a public offer. ${ }^{120}$ This confirmation must be given separately to any agreement to use the service. $^{121}$

The concern with a risk statement which can be confirmed by simply checking a box on an internet page is that proper consideration will not be given to it. The United Kingdom requires a further step where the funding portal must assess the appropriateness of an

\footnotetext{
116 At [127].

${ }^{117}$ Financial Conduct Authority, above n 1, at 13.

118 Regulation 27(1).

${ }^{119}$ Regulation 27(2).

120 Regulation 28(1).

${ }^{121}$ Regulation 28(2).
} 
unadvised investor to use its services, ${ }^{122}$ as the FCA does not think risk warnings alone provide adequate consumer protection and at the least different risk warnings are needed in different circumstances instead of a single uniform warning. ${ }^{123}$ Assessing appropriateness involves the investor providing information to the service regarding "his knowledge and experience in the investment field", from which the service will assess whether the investor has the necessary experience and knowledge to understand the risks involved. ${ }^{124}$ The restrictions ensure that "only those retail investors who can understand and bear the various risks involved are invited to invest in unlisted shares". ${ }^{125}$

Assessing investor appropriateness places a potentially heavy burden on the platform provider unless the assessment can be done through automated means. The requirement for an assessment of appropriateness could lead to access to the market being too restrictive for the average retail investor. A less arduous alternative could involve providing educational material followed by a questionnaire to demonstrate the investor's understanding, particularly of general risks and the risk of illiquidity, such as is required in the United States. ${ }^{126}$ Italy similarly requires a questionnaire to be answered in order to demonstrate understanding of the essential features and main risks involved. ${ }^{127}$ This approach would ensure investors take the time to read and process the warnings while still making it possible to administer through an automated process. Investor education requirements similar to the JOBS Act were initially proposed in New Zealand but dropped after the first round of submissions. ${ }^{128}$

Without any sort of suitability assessment, the prescribed risk warnings only protect an investor that takes the time to read them. ${ }^{129}$ If the purpose is to encourage flexibility and growth and not to protect reckless investors, a follow up test to the risk warnings may be unnecessary. On the other hand, it would not be a huge burden on the investment platform to administer a questionnaire, which would provide better education about crowd funding

122 COBS 4.7.7 R(3).

${ }^{123}$ Financial Conduct Authority, above n 1, at 41.

${ }^{124}$ COBS 10.2.1 R.

${ }^{125}$ Financial Conduct Authority "The Financial Conduct Authority places consumer protection at the heart of crowdfunding" (press release, 6 March 2014).

${ }^{126}$ Securities Act 15 USC § 77d-1(a)(4)(C).

${ }^{127}$ Commissione Nazionale per le Sociea e la Borsa, above n 51, art 15(2)(b).

${ }^{128}$ Ministry of Business, Innovation and Employment, above n 110, at 241.

129 Armillary Private Capital Financial Markets Conduct Regulations Discussion Paper - Table of Submissions (Ministry of Business, Innovation and Employment, March 2013) at 810. 
which the other jurisdictions recognise as important for encouraging growth in the emerging market.

\section{$V$ Attaching Liability}

A concern for many investors is ensuring that those responsible are held accountable where there have been breaches of the mandatory disclosure regime. Such breaches can be civil, criminal or a mixture of both. This part assesses whether liability can be appropriately attributed to platform providers and/or issuers who act under the crowd funding exclusion, noting that the liability regime under Part 3 does not apply. While there are avenues for attaching liability to both the provider and issuer, it will be harder to attach liability, penalties will be lower and accessory liability is not as accessible.

\section{A Liability for Breach of Licence Obligations under Part 6}

Civil liability occurs when a civil liability provision is breached, which includes Part 6 services provisions. ${ }^{130}$ When such a provision is contravened, the court may make a declaration of contravention ${ }^{131}$ for the purpose of enabling the FMA (or an investor) to apply for a compensatory order under s 494 or other civil liability order under s $497 .{ }^{132}$ The court may also, on the application of the FMA, make a pecuniary penalty order, payable to the Crown. ${ }^{133}$ There are two tiers of pecuniary penalties. The higher tier has a maximum pecuniary penalty the greatest of: the consideration for the transaction constituting the contravention, three times the gain made or loss avoided by the contravention, $\$ 1,000,000$ for an individual or $\$ 5,000,000$ in any other case. ${ }^{134}$ Any other civil liability provision has a maximum of $\$ 200,000$ for the individual or $\$ 600,000$ in any other case. $^{135}$

Civil liability attaches to many licence obligations, including the general reporting condition, the condition to notify the FMA regarding suspected contraventions of Part 2

\footnotetext{
130 Section 485 .

${ }^{131}$ Section 486 .

132 Section 487.

${ }^{133}$ Section 489.

${ }^{134}$ Section 490(1).

135 Section 490(2).
} 
and of the issuer cap, providing a disclosure document about the service to investors, providing risk warnings and receiving investor confirmation that they have read those risk warnings. ${ }^{136}$

The regulations do not attach civil liability to breaches of the eligibility criteria, including administering the anti-fraud policy, fair dealing policy and adequate disclosure arrangements. Breach will have licensing consequences only. ${ }^{137}$ The FMA has significant powers in the case of a licence contravention, which include censure of the licensee, requiring an action plan to be submitted, giving directions and suspending or cancelling the licence if it is satisfied the issuing requirements of s 396 are no longer met. ${ }^{138}$ The FMA may also vary or revoke, add to or substitute any conditions of the licence. ${ }^{139}$

Failure to submit an action plan or to comply with FMA directions gives rise to civil liability including a pecuniary penalty, as does failure to notify the FMA of a contravention or potential contravention of a market services licensee obligation in a material respect. ${ }^{140}$

Therefore, where a licensee is acting fraudulently and knowingly allows its processes to be contravened, civil liability including a pecuniary penalty can be attached through the failure to report the contravention. ${ }^{141}$ Liability can also attach to a licensee where it is "involved in a contravention", similar to secondary party liability under s 66 of the Crimes Act $1961 .{ }^{142}$ Where the licensee simply fails to ensure its processes are followed, such as making sure adequate disclosure is given, and is unaware that this process was not properly followed, then licensing consequences apply. This could make it difficult to find a licensee liable where an issuer makes a false or misleading statement which would appear to the licensee to be true and adequate disclosure, restricting this avenue of liability where the issuer is insolvent. In such a case though, liability would be better placed on the issuer where possible, as the issuer is the one making the disclosure about the offer through the crowd funding platform.

\footnotetext{
${ }^{136}$ Regulation 29.

${ }^{137}$ Cabinet Business Committee, above n 55, at [144].

138 Section 414.

139 Section 403(1)(b).

140 Section 449(4).

141 Section 412.

142 Section 533.
} 
Another avenue for liability against the provider is where it breaches the terms of the required client agreement. Implied into the client agreement is a duty to, when exercising any powers or performing any duties in relation to the service, "exercise the care, diligence, and skill that a prudent licensee ... would exercise in the same circumstances". ${ }^{143}$ This duty of care is similar to the duty trustees and directors owe. ${ }^{144}$ Breach would give rise to a claim for breach of contract. Trust and company law may be relevant in assessing whether the duty has been breached in any particular case.

\section{B Liability for Breach of Fair Dealing Obligations under Part 2}

Civil liability also results from breach of Part 2 of the Act, which provides for fair dealing in relation to financial products. ${ }^{145}$ The provisions in ss 19-23 apply equally to the licensee and the issuer as both are acting in trade by operating a business, activity of commerce or undertaking. ${ }^{146}$ These provisions are useful for capturing conduct of the issuer which does not come under Part 3 due to the exclusion. Section 82 is the usual method of enforcing disclosure obligations, ${ }^{147}$ but does not apply to crowd funding arrangements. Part 2 prohibits misleading or deceptive conduct generally, ${ }^{148}$ false or misleading representations about specified aspects of the financial product ${ }^{149}$ or unsubstantiated representations. ${ }^{150}$ Conduct that may mislead the public as to the nature, characteristics, suitability for a purpose or quantity of financial products and services is also prohibited. ${ }^{151}$

Intentionally including misleading information for the purposes of committing fraud is caught by these provisions, which are Part 2 fair dealing provisions and give rise to civil liability. ${ }^{152}$ Pecuniary penalties can apply to all of these provisions (excluding a contravention of the general prohibition against misleading or deceptive conduct in $\mathrm{s}$

\footnotetext{
143 Regulation 43.

144 Trustee Act 1956, ss 13B and 13C; and Companies Act 1993, s 137.

145 Section 17.

146 Section 18, definition of "trade".

147 Section 57(1)(b)(ii).

148 Section 19.

149 Section 22.

${ }^{150}$ Section 23.

${ }^{151}$ Sections 20 and 21.

152 Section 38.
} 
19). ${ }^{153}$ Attaching liability becomes difficult when an issuer overstates the prospects of their venture, such as indicating inflated profit forecasts or downplaying the risks. Jagwar Holdings established that inflated profit forecasts are misleading only where the directors who gave them did not in fact believe them to be true or had no reasonable basis on which to find them to be true. ${ }^{154}$

Statements such as overoptimistic claims of success or purposefully omitting information about the company's financial situation, such as the directors of Lombard Finance did in Jefferies $v R,{ }^{155}$ would be more difficult to bring within the scope of $\mathrm{s} 19$ as there is no requirement that material information be disclosed, only that the conduct is misleading. While such conduct likely would be misleading in many circumstances, application of the provision is unclear and creates the potential for inconsistencies or for negligent issuers to avoid liability.

Section 23 prohibits an unsubstantiated representation: a representation made by a person who has no reasonable grounds for making it, irrespective of whether it is false or misleading. This does not apply to a representation that a reasonable person would not expect to be substantiated. ${ }^{156}$

This section imposes an objective test, asking whether the grounds on which a person made a representation were reasonable ones. The application of this test is limited, as it cannot apply to representations made in disclosure documents or register entries. ${ }^{157}$ The disclosure made in reliance on the crowd funding exclusion does not come within the meaning of disclosure document. ${ }^{158}$ Therefore if an unsubstantiated representation is made, liability can be attached.

The extent to which this section applies is unclear as it is new law, included in this Act to ensure Part 2 is as close as possible to the Fair Trading Act provisions. ${ }^{159}$ Verification of

\footnotetext{
153 Section 489(3).

154 Jagwar Holdings Ltd $v$ Julian (1992) 6 NZCLC 68,040 (HC) at 104-105.

155 Jefferies $v$ R [2013] NZCA 188.

156 Section 23(3).

157 Section 26.

158 Section 6, definition of "disclosure document".

159 Cabinet Economic Growth and Innovation Committee "Financial Markets Conduct Bill: Approval of Supplementary Order Paper" (April 2013) at 65. See Fair Trading Act 1986, s 12A.
} 
claims is intended as a safeguard against misleading or deceptive conduct, ${ }^{160}$ preventing claims for example that a product is a "miracle cure" or organic when it is unclear what that claim means. ${ }^{161}$ The prohibition requires claims to be supported and justified, which increases consumer confidence by increasing the credibility of claims. ${ }^{162}$

As pecuniary penalties cannot be applied for when there is liability under s 19 , it may be more favourable to look for liability in the other provisions. The specified representations that must not be false or misleading do not cover forecasts or the financial situation of a company. ${ }^{163}$ These could potentially be argued to mislead as to the nature or characteristics of the financial product, although whether financial viability of an investment affects the inherent qualities of a product is tenuous. Liability will most likely be limited to s 19 , providing only civil penalties.

Directors of the issuer involved in the contravention are not treated as having contravened Part 2 provisions as they would be for a contravention of s $82 .{ }^{164}$ A director may still be found liable for being involved in the contravention, but this must be proven by the prosecution rather than being automatic, creating a further hurdle to liability. ${ }^{165}$

\section{Criminal Liability}

Two avenues of criminal liability may be available against an issuer acting under the $\mathrm{cl} 6$ exclusion. The Act creates a general offence for knowingly making or authorising a false or misleading statement in a document required by or for the purposes of the Act. ${ }^{166}$ This is not limited to the narrow definition of disclosure document in s 6. Any document provided by an issuer to investors in reliance on the exclusion is likely "for the purposes of the Act". The test is slightly different to $\mathrm{s} 19$, requiring the statement to be false or misleading in a "material particular". ${ }^{167}$ The offence carries a maximum sentence of five years, a fine not

\footnotetext{
${ }^{160}$ Ministry of Consumer Affairs Consumer Law Review: A Discussion Paper (June 2010) at 39.

161 At 35.

162 Ministry of Consumer Affairs Consumer Law Reform Additional Paper: Substantiation (November 2010) at 9-10.

163 Section 22.

164 Section 534.

165 Section 533

166 Section 512

167 Section 512(1).
} 
exceeding $\$ 200,000$ or both. ${ }^{168}$ This is significantly lower than contraventions of other defective disclosure provisions and has a higher mens rea standard. ${ }^{169}$

The lower restriction and higher threshold seems appropriate given the restrictions on the amounts an issuer may raise under the exclusion and the lower disclosure requirements. It would be unreasonable to impose heavy fines and a recklessness standard on issuers who can only raise up to $\$ 2,000,000$ a year and have lower disclosure standards.

Liability may also be found under the Crimes Act as recently amended, ${ }^{170}$ which criminalises the publishing of any false statement with intent to induce a person to acquire financial products under the Act, either knowing or reckless as to whether it is false in a material particular, with a maximum imprisonment of 10 years. ${ }^{171}$ This would predominantly apply to promoters but may also extend to a platform provider that let the false statement be published. ${ }^{172}$

The liability regime overall is not as clear as it is for breaches of the main inadequate disclosure provisions of the Act and generally has lower penalties. There are difficulties with holding either the provider or the issuer liable for misleading or incorrect information provided to investors. Due to these difficulties, an investor cap is necessary to mitigate loses by investors that may have no recourse against an issuer.

\section{Conclusion}

The purpose of crowd funding is to facilitate the investment of "relatively small amounts". There is no indication of what a small amount is. With no investor cap, there is the potential for an investor to contribute any amount they wish, whether it is large or small. Large investments are not what crowd funding is about and will blur the line between this

\footnotetext{
168 Section 512(2).

${ }^{169}$ Knowing or recklessly contravening s 82 can give rise to a maximum imprisonment of 10 years, a fine not exceeding $\$ 1,000,000$ or both for an individual, or a fine not exceeding $\$ 5,000,000$ in any other case. See $\mathrm{s}$ 510(3).

${ }^{170}$ Financial Markets (Repeals and Amendments) Act 2013, sch pt 1.

${ }^{171}$ Crimes Act 1961, s 242.

172 The promoter of the company NearZero received five years and three months jail time on conviction under this section, after claiming to have made a breakthrough in relation to lossless compression technology which he did not have, subsequently raising \$5,300,000: see $R v$ Whitley DC Nelson CRI-2008-042-3052, 10 August 2010 at [6].
} 
type of funding and the small offers exclusion. The small offers regime is aimed at larger investments but has other important protections such as the maximum number of 20 investors and the need for a "personal" offer, which protects the investor through the personal relationship that exists with the issuer. ${ }^{173}$

The liability regime is unclear for offers outside of Part 3 and makes it difficult for an investor to get relief where the information they based their decision to invest on was incorrect. Relief could be sought under Part 2 but is more limited, which increases the importance of protecting investors through a combination of investor caps, disclosure and risk warnings.

Disclosure for crowd funding issues will be less than what would otherwise be required if Part 3 applied. Less disclosure means less information for investors, which warrants the inclusion of other investor protection mechanisms. Although risk warnings and alternative reduced disclosure are helpful, they do little to protect an unsophisticated investor from themselves. This is particularly so if the investor can satisfy a warning requirement by checking a box on an internet page. An inexperienced investor may be prone to ignore or downplay the risks when faced with an offer hyped by the crowd to be the next big thing, leading to over investing. If they do lose their money, those investors could then turn to the government for compensation, claiming they were not properly protected.

A five per cent cap of the amount being raised in an issue per investor would be adequate to mitigate the risks of significant financial losses while still allowing for diversification of an investment portfolio. Minimum disclosure obligations should be clearly set out in the regulations, with options for either greater disclosure or stricter investor caps for raises of greater amounts, for example requiring higher level disclosure where the caps allow for an investment above $\$ 10,000$ per investor in the issuer within a 12 month period. The current approach of greater disclosure where there is no investor cap is contrary to the principles of the exclusion and does little to protect an investor from the identified risks. Given the uncertainty around liability for faulty disclosure and the significant risks of illiquidity and default, an approach that both favours the investor and keeps costs low for the issuer would be most appropriate.

173 See Lawrence, above n 21, at [31]. 


\section{Appendix: Nominee Shareholding}

Some crowd funding models involve the platform provider acting as a nominee shareholder for investors. Holding securities on behalf of investors is prohibited in the United States. ${ }^{174}$ This prohibition has been criticised as overly restrictive and discouraging diversification where investors are already limited in the amount they can invest and want to pool with other investors, deferring the management of their funds to a professional. ${ }^{175}$ In New Zealand, this approach would be categorised as a Managed Investment Scheme. ${ }^{176}$ Such an approach does not come within the definition of crowd funding and would require disclosure under Part 3 of the Act by the scheme operator. This would not prevent the scheme itself from investing in issuers looking to raise funds outside of the Act through another exclusion.

As an alternative, there is no prohibition against holding shares on behalf of the investor as a trustee, allowing for nominee shareholding as long as the investor directs what shares are acquired. This would provide a benefit to the issuer by only requiring communication to a single shareholder instead of every crowd funding investor, but does not have any obvious advantages for the investor. The investor could also call in the legal title at any time from the trustee, which ultimately defeats the purpose of such an arrangement.

\footnotetext{
${ }^{174}$ Securities Act 15 USC § 78c(a)(80)(D).

${ }^{175}$ Williamson, above n 75, at 2077.

176 Section 9(1).
} 


\section{Bibliography}

\section{A Cases}

1 New Zealand

Jagwar Holdings Ltd v Julian (1992) 6 NZCLC 68,040 (HC).

Jefferies $v$ R [2013] NZCA 188.

Lawrence $v$ Registrar of Companies [2004] 3 NZLR 37 (CA).

$R v$ Whitley DC Nelson CRI-2008-042-3052, 10 August 2010.

Securities Commission v Kiwi Cooperative Dairies Ltd [1995] 3 NZLR 26 (CA).

\section{B Legislation}

1 New Zealand

Companies Act 1993.

Crimes Act 1961.

Fair Trading Act 1986.

Financial Markets Conduct Act 2013.

Financial Markets Conduct (Phase 1) Regulations 2014.

Financial Markets Legislation (Phase 1) Commencement Order 2014.

Financial Markets (Repeals and Amendments) Act 2013.

Securities Act 1978.

Trustee Act 1956.

2 Canada

General Order 45-925 - Saskatchewan Equity Crowdfunding Exemption.

3 Italy

Decreto Crescita 2.0 (DL 179/2012 conv con L 221/2012) (translation: Growth Decree).

4 United Kingdom

Financial Services and Markets Act 2000.

Crowdfunding and the Promotion of Non-Readily Realisable Securities Instrument 2014.

5 United States

Securities Act 15 USC §§ 77a-77aa.

Jumpstart Our Business Startups Act Pub L No 112-106, 126 Stat 306 (2012). 


\section{Treaties}

Protocol on Investment to the New Zealand - Australia Closer Economic Relations Trade Agreement [2013] NZTS 1 (signed 16 February 2011, entered into force 1 March 2013).

\section{Government Publications}

1 New Zealand

Cabinet Business Committee "Financial Markets Conduct Acts and Financial Advisers Act 2008 - commencement order and regulations" (24 February 2014) (Obtained under Official Information Act 1982 Request to the Minister of Commerce).

Cabinet Business Committee "Financial Markets Conduct Regulations Paper 2: Disclosure and General Matters" (27 June 2013).

Cabinet Business Committee "Financial Markets Conduct Regulations Paper 4: Licensing regimes" (27 June 2013).

Cabinet Economic Growth and Innovation Committee "Financial Markets Conduct Bill: Approval of Supplementary Order Paper" (April 2013).

2 Italy

Commissione Nazionale per le Sociea e la Borsa Regulation on The collection of risk capital on the part of innovative start-ups via on-line portals (July 2013).

Commissione Nazionale per le Sociea e la Borsa Regalomenti emittenti (October 2013) (translation: Issuer's Regulations).

3 United Kingdom

Financial Conduct Authority Conduct of Business Sourcebook.

\section{E Papers and Reports}

1 New Zealand

Armillary Private Capital Financial Markets Conduct Regulations Discussion Paper Table of Submissions (Ministry of Business, Innovation and Employment, March 2013). Financial Markets Authority Crowd Funding Part B1: Your guide to applying for a market service licence (1 April 2014).

William Foster Financial Markets Conduct Regulations (First Exposure Draft) Regulations 2014 - Table of submissions (Ministry of Business, Innovation and Employment, February 2014).

Ministry of Business, Innovation and Employment Business Growth Agenda: Future Direction 2014 (June 2014). 
Ministry of Business, Innovation and Employment Financial Markets Conduct Bill: Officials' Report to Commerce Committee (24 July 2012).

Ministry of Business, Innovation and Employment Financial Markets Conduct Regulations (Discussion Paper, December 2012).

Ministry of Business, Innovation and Employment Financial Markets Conduct Regulations: First Exposure Draft Commentary and request for submissions (October 2013).

Ministry of Consumer Affairs Consumer Law Review: A Discussion Paper (June 2010).

Ministry of Consumer Affairs Consumer Law Reform Additional Paper: Substantiation (November 2010).

Pledgeme and Carter Kirkland Morrison Lawyers Financial Markets Conduct Regulations (First Exposure Draft) Regulations 2014 - Table of submissions (Ministry of Business, Innovation and Employment, February 2014).

Snowball Effect Financial Markets Conduct Regulations (First Exposure Draft) Regulations 2014 - Table of submissions (Ministry of Business, Innovation and Employment, February 2014).

Wynn Williams Financial Markets Conduct Regulations Discussion Paper - Table of Submissions (Ministry of Business, Innovation and Employment, March 2013).

Wynn Williams Financial Markets Conduct Regulations (First Exposure Draft) Regulations 2014 - Table of submissions (Ministry of Business, Innovation and Employment, February 2014).

\section{Australia}

Australian Government Corporations and Markets Advisory Committee Crowd sourced equity funding: Discussion Paper (September 2013).

Australian Government Corporations and Markets Advisory Committee Crowd sourced equity funding: Report (May 2014).

\section{Canada}

Canadian Securities Administrators Multilateral CSA Notice of Publication and Request for Comment: Draft Regulation 45-108 respecting Crowdfunding; Draft Policy Statement to Regulation 45-108 respecting Crowndfunding; Draft Blanket Orders in Manitoba, Québec, New Brunswick and Nova Scotia on the Start-Up Crowdfunding Prospectus and Registration Exemption; Draft Ammendments to General Order 45-925 - Saskatchewan Equity Crowdfunding Exemption (20 March 2014). 
Ontario Securities Commission Considerations for new capital raising prospectus exemptions (Consultation Paper 45-710, December 2012).

Ontario Securities Commission Introduction of Proposed Prospectus Exemptions and Proposed Reports of Exempt Distribution in Ontario (OSC Bulletin Volume 37, Issue 12 (Supp-3) 20 March 2014).

\section{United Kingdom}

Financial Conduct Authority The FCA's regulatory approach to crowd funding over the internet (policy statement 14/4, United Kingdom, 6 March 2014).

Financial Conduct Authority The FCA's regulatory approach to crowdfunding (and similar activities) (Consultation Paper 13/13, United Kingdom, 24 October 2013).

\section{United States}

United States Securities and Exchange Commission Crowdfunding: Proposed Rules (23 October 2013).

\section{F Journal Articles}

Chee Keong Low "Cornerstone Investors and Initial Public Offerings on the Stock Exchange of Hong Kong" (2009) 14 FJCFL 639.

James J Williamson "The JOBS Act and Middle-Income Investors: Why It Doesn't Go Far Enough" (2013) 122 Yale LJ 2069 at 2075.

\section{G Internet Materials}

Eleanor Kirby and Shane Worner "Crowd-funding: An Infant Industry Growing Fast" (February 2014) International Organization of Securities Commissions <www.iosco.org>. Massolution "2013CF: The Crowdfunding Industry Report" (11 April 2013) Crowdsourcing <www.crowdsourcing.org $>$.

Seed Invest "Frequently Asked Questions: What do I need to know about early-stage Investing? Are these Investments risky?" < www.seedinvest.com>.

\section{H Newspaper and Magazine Articles}

Hayley Buckley "Exploding the crowdfunding myths" The National Business Review (online ed, New Zealand, 12 April 2014).

Deborah Gage "The Venture Capital Secret: 3 Out of 4 Start-Ups Fail" The Wall Street Journal (online ed, New York, 19 September 2012). 
Brian Korn "SEC Proposes Crowdfunding Rules" Forbes (online ed, New York, 23 October 2013).

Ari Levy "Crowdfunding Lures Investors Seeking Stock Over Goggles" Bloomberg News (online ed, New York, 9 April 2014).

"Equity crowd funding a 'high risk of failure"' The New Zealand Herald (online ed, Auckland, 23 April 2014).

Lucy Warwick-Ching, Tanya Powley and Elaine Moore " Alarm bells for crowdfunding as bubble pops for soap start-up" Financial Times (online ed, London, 31 July 2013).

Samantha White "UK Financial Conduct Authority issues new regulation on crowdfunding" Chartered Global Management Accountant Magazine (online ed, Durham (NC), 6 March 2014).

\section{Press Releases}

Financial Conduct Authority "The Financial Conduct Authority places consumer protection at the heart of crowdfunding" (press release, 6 March 2014).

Financial Markets Authority "FMA issues first equity crowd funding licences" (press release, 31 July 2014).

Minister of Commerce "Crowd funding gets green light" (press release, 27 February 2014).

United States Securities and Exchange Commission "SEC Issues Proposal on Crowdfunding" (press release, 23 October 2013).

The word count of this essay is 8,000 words (including 83 words in substantive footnotes) excluding the title page, table of contents, abstract, bibliographical footnotes, bibliography and appendix. 